\title{
Monitoring selective logging in western Amazonia with repeat lidar flights
}

\author{
Hans-Erik Andersen ${ }^{a}$, Stephen E. Reutebuch ${ }^{\text {a, } *}$, Robert J. McGaughey ${ }^{a}$, \\ Marcus V.N. d'Oliveira ${ }^{\text {b }}$, Michael Keller ${ }^{c, d}$ \\ a USDA Forest Service, Pacific Northwest Research Station, University of Washington, PO Box 352100, Seattle, WA, USA \\ ${ }^{\mathrm{b}}$ EMBRAPA-CPAF-ACRE, Caixa Postal 392, CEP 69900-180 Rio Branco, Brazil \\ c USDA Forest Service, International Institute of Tropical Forestry, San Juan, PR, USA \\ d EMBRAPA-CNPM, Campinas, São Paulo, Brazil
}

\section{A R T I C L E I N F O}

Article history:

Received 27 December 2012

Received in revised form 3 August 2013

Accepted 6 August 2013

Available online $\mathrm{xxxx}$

\section{Keywords:}

Forest biomass

Airborne laser scanning

Selective logging

Tropical forest management

Lidar

Amazon forest monitoring

\begin{abstract}
A B S T R A C T
The objective of this study was to test the use of repeat flight, airborne laser scanning data (lidar) for estimating changes associated with low-impact selective logging (approx. $10-15 \mathrm{~m}^{3} \mathrm{ha}^{-1}=5-7 \%$ of total standing volume harvested) in natural tropical forests in the Western Brazilian Amazon. Specifically, we investigated change in area impacted by selective logging, change in tall canopy ( $30 \mathrm{~m}+$ ) area, change in lidar canopy structure metrics, and change in above ground biomass (AGB) using a model-based statistical framework. Ground plot measurements were only available from the time of the 2010 lidar acquisition. A simple differencing of the 2010 and 2011 lidar canopy height models identified areas where canopy over $30 \mathrm{~m}$ tall had been removed. Area of tall canopy dropped from $22.8 \%$ in 2010 to $18.7 \%$ in 2011 , a reduction of $4.1 \%$. Using a relative density model (RDM) technique the increase in area of roads, skidtrails, landings, and felled tree gaps was estimated to be $17.1 \%$. A lidar-based regression model for estimating AGB was developed using lidar metrics from the 2010 lidar acquisition and corresponding AGB ground plot measurements. The estimator was then used to compute AGB estimates for the site in 2010 and 2011 using the 2010 and 2011 lidar acquisition data, respectively. A model-based statistical approach was then used to estimate the uncertainty of the changes in AGB between the acquisitions. Change in RDMs between lidar acquisitions was used to classify each $50 \mathrm{~m}$ cell in the study area as impacted or non-impacted by logging. The change in mean AGB for the entire study area was $-9.1 \mathrm{Mg} \mathrm{ha}^{-1} \pm 1.9$ (mean $\left.\pm \mathrm{SD}\right)(P$-value $<0.0001)$. The change in mean AGB for areas newly impacted in 2011 was $-17.9 \pm 3.1 \mathrm{Mg} \mathrm{ha}^{-1}(P$-value $<0.0001)$ while the change in mean AGB for non-impacted areas was significantly less at $-2.6 \pm 1.1 \mathrm{Mg} \mathrm{ha}^{-1}(P$-value $=0.009)$. These results provide corroborating evidence of the spatial extent and magnitude of change due to low-intensity logging in tropical forests with heavy residual canopy cover.
\end{abstract}

Published by Elsevier Inc.

\section{Introduction}

Selective logging of high value timber is an important land use in the Brazilian Amazon (Asner et al., 2005) and in other tropical regions (Curran et al., 2004; Wright, 2010). At the beginning of this century, the area of Brazilian forest subjected to selective logging was similar to the area deforested (Asner et al., 2005). Both deforestation (INPE, 2013) and logging activities (Pereira, Santos, Vedoveto, Guimarães, \& Veríssimo, 2010) have declined at similar rates in the Brazilian Amazon but despite these declines both activities still affect several thousand square kilometers of forest area every year.

Reducing Emissions from Deforestation and Forest Degradation (REDD) has been proposed as a means to mitigate carbon dioxide emissions (Angelsen, 2008). Gross carbon dioxide emissions from tropical

\footnotetext{
* Corresponding author. Tel.: +1 2065434710.

E-mail address: sreutebuch@fs.fed.us (S.E. Reutebuch).
}

deforestation (excluding regrowth and carbon losses from peat and mineral soil) accounted for approximately $0.8 \mathrm{Pg}-\mathrm{C}(1 \mathrm{Pg}=1015 \mathrm{~g})$ during the period 2000 to 2010 or approximately $10 \%$ of global anthropogenic carbon dioxide emissions (Baccini et al., 2012; Harris, Brown, Hagen, Baccini, \& Houghton, 2012; Harris, Brown, Hagen, Saatchi, et al., 2012). The carbon released from forest degradation is highly uncertain because both the area affected and carbon loss through degradation are poorly quantified. In Brazil, logging, an important degradation pathway, may have emitted as much as $0.1 \mathrm{Pg}_{-} \mathrm{C} \mathrm{y}^{-1}$ from 1999 to 2002 (Asner et al., 2005).

Logging damage is generally quantified not in carbon terms but rather in terms of ground damage and canopy damage either as a proportion of area logged or on a per tree harvested basis (Pereira, Zweede, Asner, \& Keller, 2001, 2002; Picard, Gourlet-Fleury, \& Forni, 2012). Carbon dioxide emissions from logging depend on the original forest carbon stocks, the intensity of logging, the quality of the logging management, and the rate of recovery following logging (Keller, Asner, Silva, \& Palace, 2004; 
Keller, Palace, Asner, Pereira, \& da Silva, 2004; Pinard \& Putz, 1996). Because adequate field sampling of remote logged forest areas is costly and difficult (d'Oliveira, Reutebuch, McGaughey, \& Andersen, 2012), we have few data on carbon losses caused by logging and as such a great uncertainty regarding the potential for carbon mitigation for REDD by improved management of tropical selective logging.

Prompted by the international Governor's Climate and Forests Task Force, the Brazilian State of Acre is implementing a sustainable development policy that aims to promote integrated forest management, where the native forests are providers of products (timber and non-timber) and environmental services. The main objective is to aggregate value to the standing forest, avoid deforestation and mitigate the climatic change effects of forest destruction and degradation. This policy permits Acre to participate in REDD carbon markets. In 2010 Acre enacted a law to create the State System of Incentives for Environmental Services (SISA). SISA establishes the legal and institutional framework for planning, monitoring, and marketing carbon credits associated with sustainable forest management practices (Acre State, 2010; Acre. Governo Do Estado Do Acre, 2012). Economical, rapid, and reliable methods for measuring carbon changes over large areas of managed forests would assist Acre State with monitoring SISA efforts.

In remote forest areas, where ground-based monitoring of forest carbon stocks is costly and difficult, lidar may be a valuable tool for estimation of forests carbon stocks, carbon stock changes, and forest degradation through logging. Many studies have demonstrated that smallfootprint airborne lidar systems can be used to estimate above ground biomass (AGB) in forest types ranging from boreal to tropical (e.g., Andersen, Strunk, \& Temesgen, 2011; Asner et al., 2010, 2011, 2012; Beets et al., 2011; d'Oliveira et al., 2012; Gobakken et al., 2012; Gonzalez et al., 2010; Hudak et al., 2012; Koch, 2010; Li, Andersen, \& McGaughey, 2008; Næsset, 2011; Næsset \& Gobakken, 2008; Nyström, Holmgren, \& Olsson, 2012). There are limited studies on the estimation of structural and biomass change in temperate forests using lidar data (Bollandsås, Gregoire, Næsset, \& Øyen, 2013; St-Onge \& Vepakomma, 2004; Yu, Hyyppa, Hyyppa, \& Maltamo, 2004) and even fewer in tropical forests (Dubayah et al., 2010; Kellner, Clark, \& Hubbell, 2009; Meyer et al., 2013), these studies focus on unmanaged tropical forests. Almost no effort has been made to investigate the use of airborne lidar to detect selective logging in tropical forests. Weishampel, Hightower, Chase, and Chase (2012) compared lidar estimates of canopy gaps with Landsat estimates of deforestation for the Caracol Archaeological Reserve in Belize and concluded that lidar can be used as a tool for monitoring fine-scale canopy changes in areas affected by selective logging.

In a study conducted in Antimary State Forest (FEA), Acre State, Brazil, d'Oliveira et al. (2012) used lidar data to map forest biomass in areas of low-intensity selective logging. Using near-ground lidar return density, rather than overstory canopy gaps, d'Oliveira et al. (2012) successfully mapped roads, skid-trails, landings and tree gaps under heavy residual canopy. In 2011, selective logging of the FEA study site was completed and a second lidar dataset was acquired. Our current study adds a temporal dimension to the predecessor study by use of lidar data collected in May-June 2010 (prior to logging in the northern two-thirds of the area) and in November 2011 after selective logging operations had been completed. We investigate how lidar acquired before and after logging can be used to quantify changes in canopy structure and AGB, both over the entire study area and specifically in areas affected by selective logging, thereby complementing the work of d'Oliveira et al. (2012). The objectives of the follow-up study herein reported were to: 1) investigate changes in lidar canopy structure metrics used in AGB estimation that were observed between lidar acquisitions; 2) demonstrate how a lidar model-based approach can be used to estimate change in AGB associated with low intensity selective logging; and, 3) demonstrate how changes in area of logging roads, skidtrails, landings, and large tree gaps can be mapped using relative density models (RDM).

\section{Materials}

\subsection{Study site}

The study area is located in FEA, $90 \mathrm{~km}$ northwest of the city of Rio Branco, Acre State, Brazil. It is a 1000 ha block of mature tropical forest from natural origins. In the study area there are predominately two types of forest: dense tropical forests with uniform canopy and emergent trees and open tropical forests with large occurrence of lianas and palm trees. The area has rolling topography with annual precipitation of $2000 \mathrm{~mm}$. Under a management plan administered by Acre State Government a volume of approximately $10-15 \mathrm{~m}^{3}$ (approximately $12-18 \mathrm{Mg} \mathrm{ha}^{-1} \mathrm{AGB}$ ) of merchantable timber was harvested throughout the entire site using selective logging methods (d'Oliveira et al., 2012). At the time of the first lidar acquisition (29 May, 2-3 June 2010), most of the roads and skidtrails had been built and the majority of the trees planned for harvest had been felled in the southern one third of the study area. By the time of the second lidar acquisition (29 November 2011), road building and selective logging operations had been nearly completed throughout the entire study area.

\subsection{Field data and biomass calculations}

A forest inventory was conducted in May 2010 immediately before the first lidar flight. The inventory used a systematic random sample (SRS) with plots that were nominally $50 \mathrm{~m} \times 50 \mathrm{~m}$ in size, evenly distributed along ten lines with a total of 50 sample plots and a total sampled area of 12.5 ha or $1.25 \%$ of the total study area (Fig. 1). All plants greater than $10 \mathrm{~cm}$ diameter at breast height (DBH) were labeled, measured and identified. Oven-dry AGB (Mg) was estimated for each plot using an allometric equation developed for a similar forest in the southern Amazon (Nogueira, Fearnside, Nelson, Barbosa, \& Keizer, 2008).

$\mathrm{AGB}=\exp \left(-1.716+2.413^{*} \operatorname{Ln}(\mathrm{DBH})\right) / 1000$.

AGB includes bark, bole, branches, foliage, and flowering materials above the ground surface. AGB in the ground plots varied from 96.9 to $493.6 \mathrm{Mg} \mathrm{ha}^{-1}$ (mean $230.9 \pm 10.5 \mathrm{SE}$ ). Details of plot location, layout, measurement protocols, and range of observed AGB are found in d'Oliveira et al. (2012).

\subsection{Lidar data sets}

Two high-density discrete return lidar datasets were collected over the study site. Both datasets were acquired by the same lidar vendor using the same lidar sensor and with similar sensor settings and flight parameters (Table 1). The 2010 dataset had a pulse density of $25 \mathrm{~m}^{-2}$ and above ground flying height of $500 \mathrm{~m}$, compared to $14 \mathrm{~m}^{-2}$ and $600 \mathrm{~m}$ for the 2011 data. For both acquisitions, the lidar vendor delivered LAS point files, filtered ground point files, and 1-m resolution bare earth digital terrain models (DTM). The expected positional accuracy $(1 \sigma)$ of the lidar measurements is approximately $0.1 \mathrm{~m}$ horizontal and $0.12 \mathrm{~m}$ vertical (Optech Inc., 2008).

Many studies have documented that changes in sensor model, sensor settings, flight parameters, and seasonal foliage status (leaf-on; leaf-off) can cause changes in computed lidar metrics (Chasmer, Hopkinson, Smith, \& Treitz, 2006; Goodwin, Coops, \& Culvenor, 2006; Hopkinson, 2007; Magnussen, Næsset, \& Gobakken, 2010; Magnusson, Fransson, \& Holmgren, 2007; Morsdorf, Frey, Meier, Itten, \& Allgöwer, 2008; Næsset, 2009). Fortunately, in this study, with the exception of pulse density, sensor and flight, parameters were very similar between the 2010 and 2011 lidar datasets. Magnussen et al. (2010) concluded that when pulse density is greater than approximately $1 \mathrm{~m}^{-2}$, effects on computed lidar metrics should be very limited and calibration 


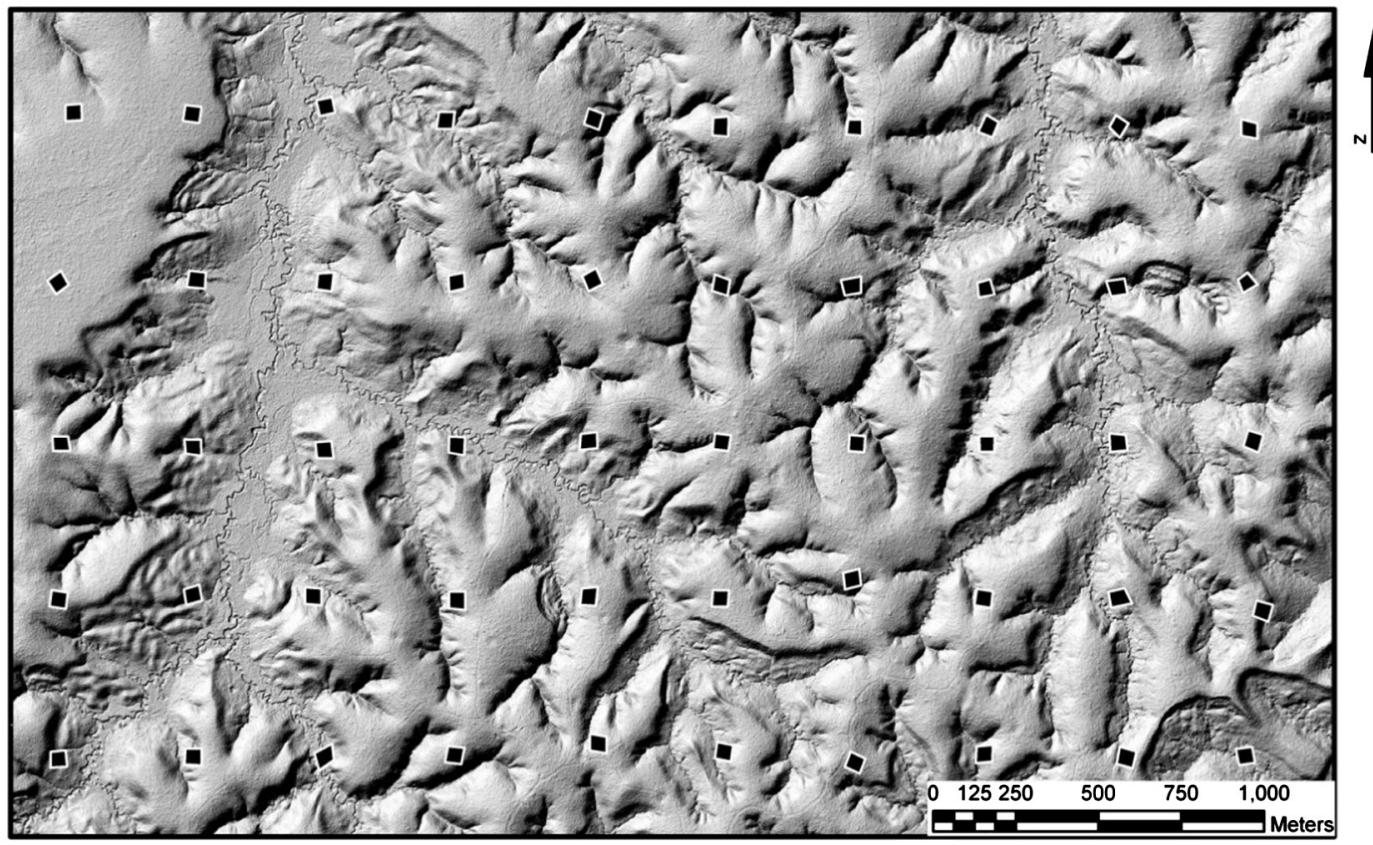

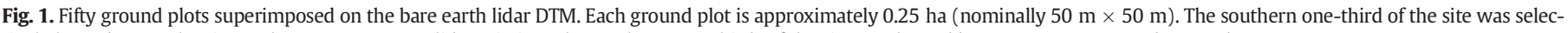
tively logged a month prior to the May-June 2010 lidar mission. The northern two-thirds of the site was logged between June 2010 and November 2011.

between lidar datasets would not be warranted; therefore, no thinning of the 2010 lidar data was performed and the datasets were used at their acquired data densities.

\section{Lidar processing}

\subsection{Calculation of 2010 and 2011 plot-level lidar forest structure metrics}

The FUSION "PolyClipData" routine (McGaughey, 2010) was used to extract all returns (first, intermediates, and last returns per pulse) from the 2010 and 2011 LAS files that fell within the boundaries of each ground plot. The ground surface elevation (interpolated from the 2010 bare earth DTM) was then subtracted from each return to normalize topographic variation between plots (the mean difference between the 2010 and 2011 DTMs was $0.030 \mathrm{~m}$ ). The FUSION “CloudMetrics” routine was used to compute descriptive statistics for the lidar point cloud vertical structure for each plot in 2010 and 2011 (Table 2). A 1 m minimum height above ground threshold was used to exclude returns from lowlying vegetation and the ground surface. A canopy overstory threshold

Table 1

2010 and 2011 lidar acquisition specifications.

\begin{tabular}{lll}
\hline Specification & 2010 & 2011 \\
\hline Aircraft (twin-engine, fixed-wing) & Embraer 810 Sêneca II & Embraer 810 Sêneca II \\
Lidar sensor & Optech ALTM 3100EA & Optech ALTM 3100EA \\
Acquisition dates & 29 May, 2-3 June & 23 November \\
Approx. flightline separation (m) & 40 & 65 \\
Above ground flying height (m) & 500 & 600 \\
Beam Divergence mrad (1/e) & 0.25 & 0.25 \\
Scan angle ( \pm degrees off nadir) & 5.5 & 6 \\
Swath width (m) & 95 & 125 \\
Swath sidelap (\%) & $60 \%$ & $50 \%$ \\
Scan rate (hz) & 70 & 70 \\
Pulse rate (Khz) & 50 & 50 \\
Pulse density (m ${ }^{-2}$ ) & 25 & 14 \\
\hline
\end{tabular}

height of $2 \mathrm{~m}$ was used to compute lidar canopy cover metrics. The 2010 plot-level lidar metrics were merged with the summarized 2010 field plot data for regression modeling with the $\mathrm{R}$ statistical package ( $\mathrm{R}$ Development Core Team, 2012).

\subsection{Regression model of $A G B$ and change estimation}

\subsubsection{AGB regression model}

Using the 2010 lidar plot-level metrics, multiple linear regression techniques were used to develop relationships between lidar metrics (Table 2) and field-measured AGB. Lidar predictor variables were selected using the best subsets approach (R Package 'leaps', Lumley, 2009 ) in the $\mathrm{R}$ statistical package ( $\mathrm{R}$ Development Core Team, 2012). Highly collinear predictor variables were dropped from the model.

\subsubsection{Lidar estimates of 2010 and 2011 AGB and AGB change}

Using the FUSION "GridMetrics" routine the area-based lidar metrics identified as predictor variables in the AGB regression were computed over the entire study area at $50 \mathrm{~m}$ resolution. The lidar regression model and the 2010 and 2011 lidar predictor raster layers were then used in GIS to map AGB estimates across the study area. Change in estimated mean AGB was then computed by subtracting the 2010 mean AGB raster values from the 2011 values (Fig. 2).

A model-based approach was used to estimate the uncertainty (i.e. variance) of the estimated difference in mean AGB between 2010 and 2011 both across the entire study area and within impacted and non-impacted areas (see Section 3.3.2 for description of logging impact areas). The methodology described by McRoberts, Næsset, and Gobakken (2013) for estimating the mean, and corresponding variance, of forest growing stock volume in a lidarassisted, model-based statistical framework was extended to allow for estimating the mean, and variance, of AGB change at the Antimary site. 
Table 2

Summary of the lidar forest structure variables derived from the lidar point cloud for each ground plot and for each $50 \mathrm{~m}$ by $50 \mathrm{~m}$ grid cell in the study area.

Minimum height above ground
Maximum height above ground
Mean height above ground
Quadratic mean height above ground
Median height above ground
Mode height above ground
Standard deviation of height above ground
Variance of height above ground
Coefficient of variation of height above ground
Interquartile distance of height above ground
Skewness of height above ground
Kurtosis of height above ground
AAD (average absolute deviation from the mean height) of height above ground
Height L-moments (L1, L2, L3, L4)
Height L-moment skewness
Height L-moment kurtosis
Percentile height values (1st, 5th, 10th, 20th, 25th, 30th, 40th, 50th, 60th, 70th,
75th, 80th, 90th, 95th, 99th percentiles) of height above ground
Percentage of first returns above a specified height (canopy cover estimate)
Percentage of first returns above the mean height
Percentage of first returns above the mode height
Percentage of all returns above a specified height (alternate canopy cover estimate)
Percentage of all returns above the mean height
Percentage of all returns above the mode height

\subsubsection{Variance estimation for lidar-based AGB change}

As stated in McRoberts et al. (2013), the main assumption of modelbased inference is that each observation is a random variable with a distribution of possible values. The main limitation of model-based inference is that the estimates are not necessarily unbiased. However, in the case of the Antimary study, the use of a model-based approach allows for the estimate of AGB change, and an estimate of the precision of this estimate, even without field-based measurements of AGB in 2011. Again, following McRoberts et al. (2013), if $Y$ is the random variable (AGB) with a mean $\mu$ and standard deviation $\sigma$ the observed AGB value at the $i$ th pixel $\left(y_{i}\right)$ can be represented as: $y_{i}=\mu_{i}+\epsilon_{i}$ where $\in_{i} \sim N\left(0, \sigma^{2}\right)$. The mean $\mathrm{AGB}$ at the $i$ th pixel is then given by $\mu_{i}=f\left(\mathbf{X}_{i} ; \boldsymbol{\beta}\right)$ which is estimated by $\hat{\mu}_{i}=f\left(\boldsymbol{X}_{\boldsymbol{i}} ; \hat{\boldsymbol{\beta}}\right)$, where $\mathbf{X}_{\mathbf{i}}$ is the vector of lidar-based predictor variables (P25 and VAR) at the $i$ th pixel (available for 2010 and 2011) and $\hat{\beta}$ is the vector of $P$ predicted regression coefficients.

The variance of the difference in the estimated mean biomass between $2011\left(\frac{1}{N} \sum_{i=1}^{N} \hat{\mu}_{i_{2011}}\right)$ and year $2010\left(\frac{1}{N} \sum_{i=1}^{N} \hat{\mu}_{i_{2010}}\right)$ is given by:

$$
\begin{aligned}
& \hat{V}\left[\frac{1}{N} \sum_{i=1}^{N} \hat{\mu}_{i_{2011}}-\frac{1}{N} \sum_{i=1}^{N} \hat{\mu}_{i_{2010}}\right]=\frac{1}{N^{2}} \hat{V}\left[\sum_{i=1}^{N} \hat{\mu}_{i_{2011}}-\hat{\mu}_{i_{2010}}\right] \\
& =\frac{1}{N^{2}} \sum_{i=1}^{N} \sum_{j=1}^{N} \widehat{\operatorname{Cov}}\left(\hat{\mu}_{i_{2011}}-\hat{\mu}_{i_{2010}}, \hat{\mu}_{j_{2011}}-\hat{\mu}_{j_{2010}}\right) \\
& =\frac{1}{N^{2}} \sum_{i=1}^{N} \sum_{j=1}^{N} \boldsymbol{Z}_{i_{2011}^{\prime}} \boldsymbol{V}_{\hat{\beta}} \boldsymbol{Z}_{j_{2010}}
\end{aligned}
$$

where $\boldsymbol{V}_{\hat{\beta}}$ is the variance-covariance matrix for the regression model parameter estimates, which in the case of $P=2$ (such as this study), is given by:

$$
\boldsymbol{V}_{\hat{\beta}}=\left[\begin{array}{ccc}
\hat{V}\left(\hat{\beta}_{0}\right) & \widehat{\operatorname{Cov}}\left(\hat{\beta}_{0}, \hat{\beta}_{1}\right) & \widehat{\operatorname{Cov}}\left(\hat{\beta}_{0}, \hat{\beta}_{2}\right) \\
\widehat{\operatorname{Cov}}\left(\hat{\beta}_{1}, \hat{\beta}_{0}\right) & \hat{V}\left(\hat{\beta}_{1}\right) & \widehat{\operatorname{Cov}}\left(\hat{\beta}_{1}, \hat{\beta}_{2}\right) \\
\widehat{\operatorname{Cov}}\left(\hat{\beta}_{2}, \hat{\beta}_{0}\right) & \widehat{\operatorname{Cov}}\left(\hat{\beta}_{2}, \hat{\beta}_{1}\right) & \hat{V}\left(\hat{\beta}_{2}\right)
\end{array}\right]
$$

and the elements of $\mathbf{Z}$ given by:

$Z_{s j}=\frac{\partial\left(\boldsymbol{X}_{s_{2011}}-\boldsymbol{X}_{s_{2010}} ; \hat{\boldsymbol{\beta}}\right)}{\partial \beta_{j}}$.

This variance formulation was confirmed using a Monte Carlo simulation approach, where 100,000 random samples from the sampling distribution of the estimated regression model coefficients $\left(\left(N_{3}\left(\hat{\beta}, V_{\hat{\beta}}\right)\right)\right)$ were drawn and used to predict mean AGB for 2010 and 2011 over the entire study area. The difference between the mean AGB for 2010 and 2011 was then calculated at each iteration of the simulation, and after 100,000 iterations an estimate of the sampling distribution of the difference between the means was obtained. The variance of the sampling distribution obtained via Monte Carlo simulation was very close to that obtained using the analytical variance estimator given above; and furthermore, confirmed our expectation that the distribution of the difference between means was normally distributed ( $P$-value for ShapiroWilk test of normality $=0.997$ ).

\subsection{Canopy height models and relative density models (RDMs)}

\subsubsection{Calculation of change in high canopy area from canopy height models}

The highest return in each $1 \mathrm{~m}^{2}$ area was used to create $1 \mathrm{~m}$ resolution canopy surface models (CSM) for each lidar dataset. The 2010 DTM was then subtracted from each CSM to create $1 \mathrm{~m}$ resolution canopy height models (CHM) for 2010 and 2011. ArcGIS Spatial Analyst Raster Calculator (ESRI, 2011) was used to map areas with canopy height greater than $30 \mathrm{~m}$ in 2010 and 2011 . Change in areas with canopy height greater than $30 \mathrm{~m}$ was then mapped by subtracting the 2010 areas from the 2011 areas.

\subsubsection{Calculation of change in area impacted by logging from relative density models}

The FUSION "Cover" algorithm was used to create $1 \mathrm{~m}$-resolution RDMs using the 2010 and 2011 lidar datasets. The RDMs were used to identify areas impacted by roads, skidtrails, landings, and tree gaps associated with selective logging (Fig. 3). A RDM is a raster layer of the relative percentage of lidar returns within a user-specified above ground height stratum. For each raster, the percentage value was computed by dividing the number of returns in the height stratum from $1 \mathrm{~m}$ to $5 \mathrm{~m}$ above ground by the total number of returns below 5 m, multiplied by 100 (d'Oliveira et al., 2012, Fig. 3).

By examining the 2010 and 2011 RDMs, the areas impacted by forest operations (roads, landings, skidder trails and canopy gaps due to tree removal) were visually distinguished from the undisturbed areas. The impacted areas were manually digitized in GIS. A $6 \mathrm{~m}$ buffer was added to the digitized centerlines of main roads and a $4 \mathrm{~m}$ buffer to skidtrails. A $20 \mathrm{~m}$ buffer was added to the digitized center point of landings and a $25 \mathrm{~m}$ buffer to harvested tree gaps to account for typical widths of these features (Fig. 4). The polygons of buffered impacted areas were converted to a $5 \mathrm{~m}$ resolution raster. For each year, this $5 \mathrm{~m}$ impact raster was intersected with the lidar-predicted AGB raster ( $50 \mathrm{~m}$ resolution). Those cells in the AGB raster that contained impacted cells were classified as disturbed to some degree by selective harvesting. Change in area of impacted area was computed by summing the area of the $50 \mathrm{~m}$ impacted cells for each lidar acquisition.

\subsection{Differences between 2010 and 2011 lidar canopy metrics}

Although ground plot remeasurement data were not available for 2011, because of the similar acquisition parameters, the lidar metrics computed from each acquisition's point cloud are repeat measurements that can be compared for the purpose of understanding change in the 
forest canopy structure associated with selective logging. The 2010 and 2011 lidar datasets were analyzed for significant differences in the lidar metrics selected as explanatory variables in the AGB model. Two-tailed paired t-tests were conducted between the 2010 and 2011 AGB model explanatory variables for the 50 ground plots and for the set of $50 \mathrm{~m}$ cells where new logging impacts were identified via changes in the RDMs.

\section{Results}

\subsection{Lidar AGB regression model}

A multiple linear regression model using: 1) the 25th percentile height above ground of all lidar returns (P25); and, 2) the variance of all lidar return heights above ground (VAR) as predictor variables
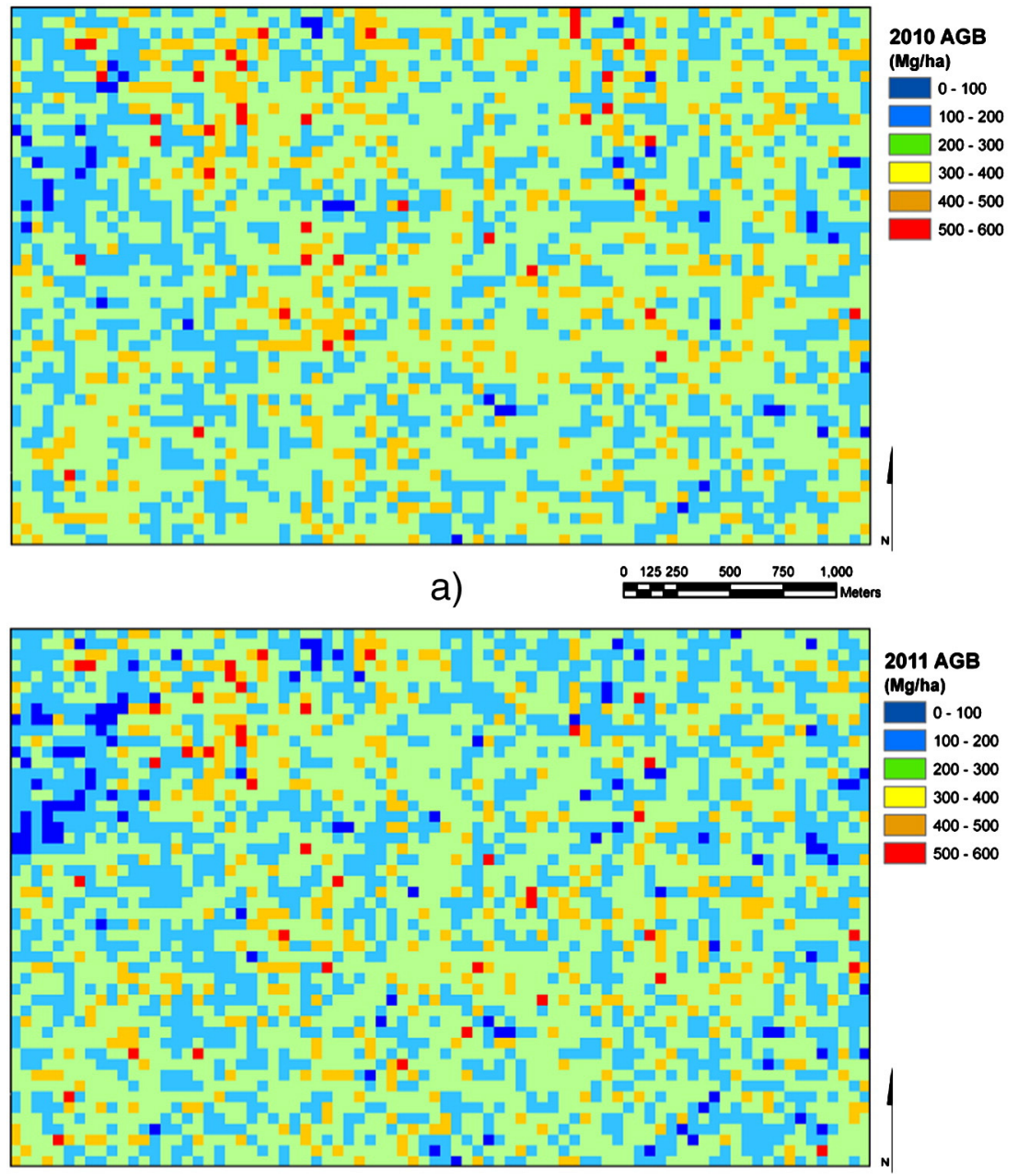

2011 AGB

(Mg/ha)

0.100

$100 \cdot 200$

$200-300$

$\square 300-400$

$400-500$

$500-600$

b)

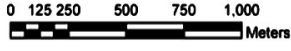

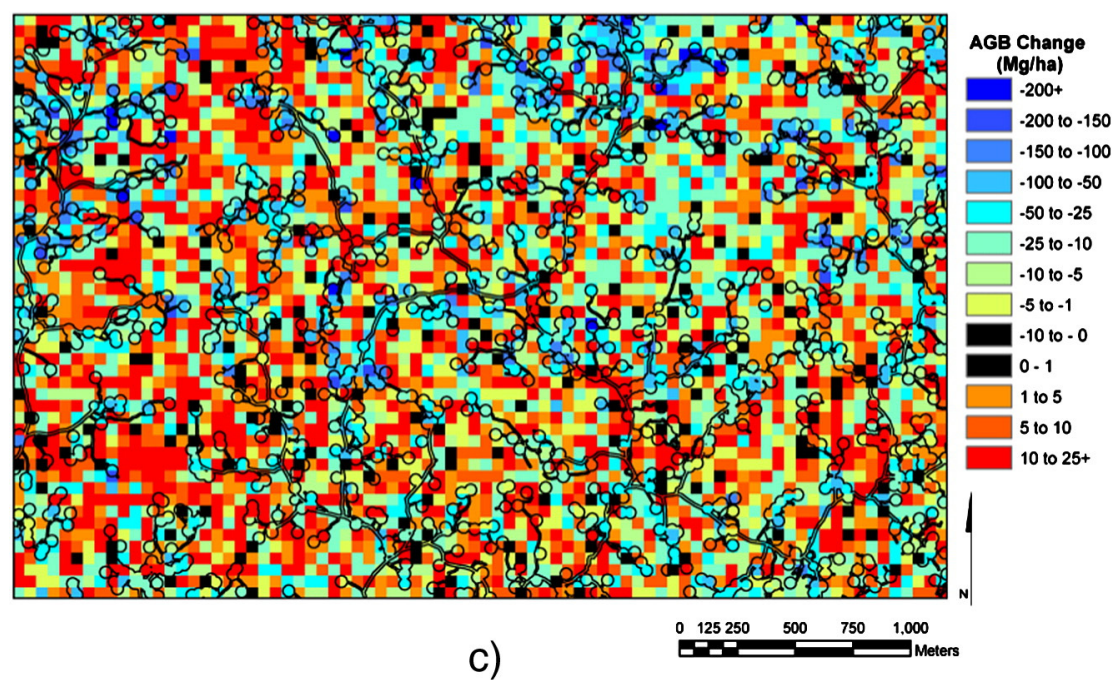

Fig. 2.2010 (a), 2011 (b), and change (c) in AGB estimated at $50 \mathrm{~m}$ raster resolution with the lidar regression model. Impacted areas identified by the 2011 RDM are superimposed (black outlines). 

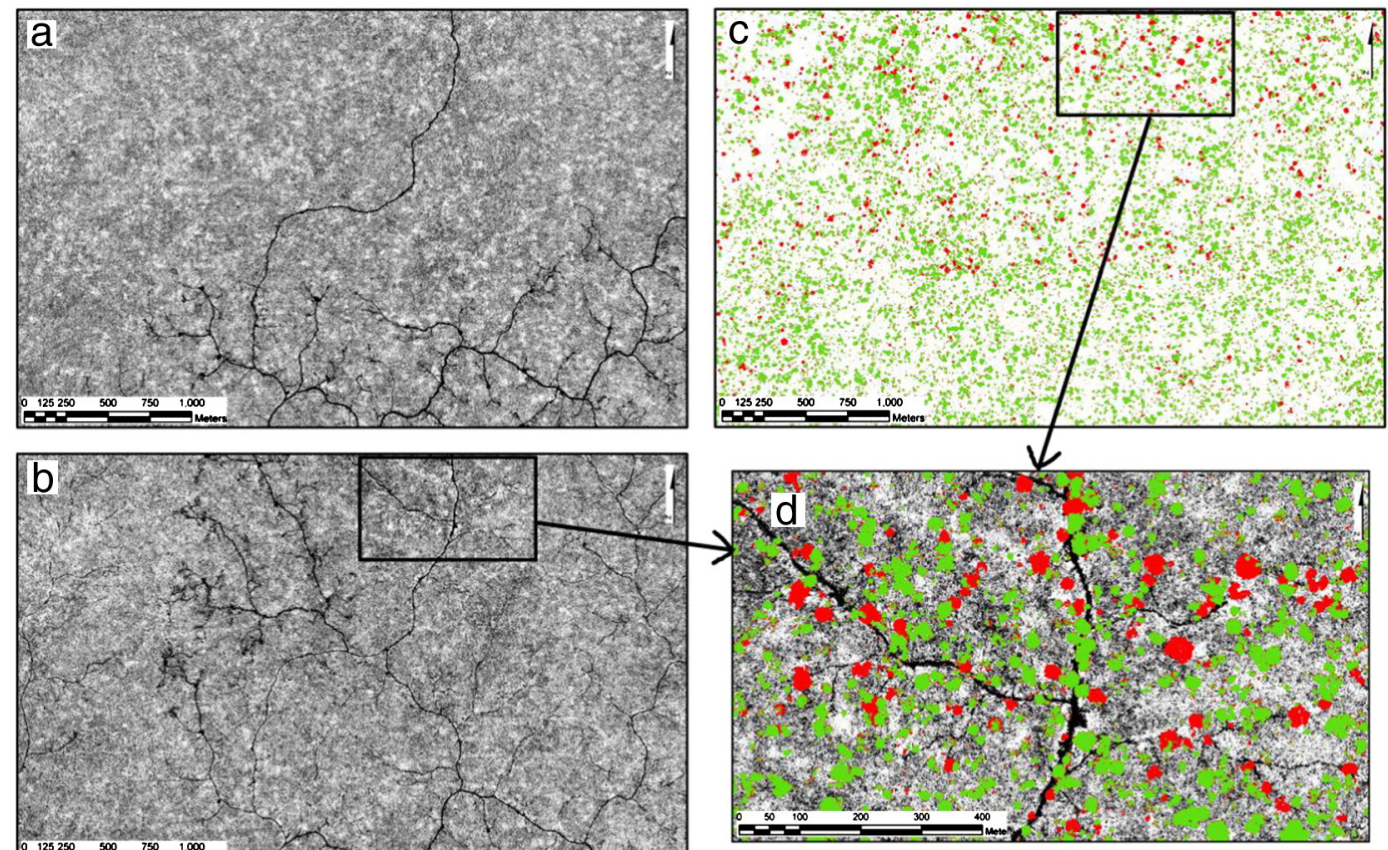

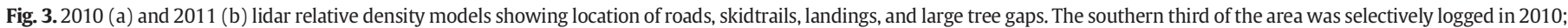

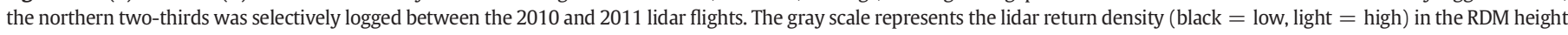

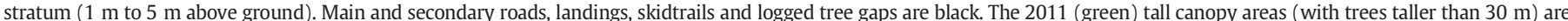

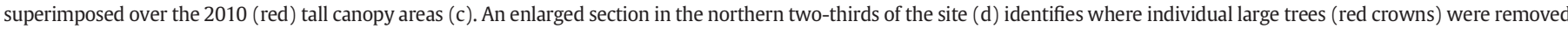
between lidar acquisitions. (For interpretation of the references to colors in this figure legend, the reader is referred to the web version of this article.)

provided a robust, parsimonious regression model for AGB (Table 3 ). The multiple $R^{2}$ value for this model is 0.70 and the standard error of the regression is $41.5 \mathrm{Mg} \mathrm{ha}^{-1}$.

\subsection{Estimated changes in area impacted by selective logging, $A G B$, and high canopy}

The RDMs show that between the 2010 and 2011 lidar acquisitions, roads, skidtrails, and landings were built throughout the northern twothirds of the study area that had not been logged in 2010 (Fig. 3). For the total study site the proportion of $50 \mathrm{~m}$ cells that contained some level of logging disturbance identified via the RDMs changed from 21.2\% to 62.9\% (Fig. 4; Table 4). Between lidar acquisitions change in mean AGB for the entire study area was $-9.1 \mathrm{Mg} \mathrm{ha}^{-1} \pm 1.9$ (mean \pm SD) (Table 4). A significance test (assuming that the sampling distribution of the difference between means is normally distributed, as confirmed via Monte Carlo simulation - see Section 3.2.3) indicated that the difference was statistically significant $(P$-value $<0.0001)$. The change in mean AGB in $50 \mathrm{~m}$ cells that were not newly impacted in 2011 was $-2.6 \pm 1.1 \mathrm{Mg} \mathrm{ha}^{-1}(P$-value $=0.01)$; whereas, the change in mean AGB for newly impacted cells was $-17.9 \pm 3.1 \mathrm{Mg} \mathrm{ha}^{-1}$ $(P$-value $<0.0001)$. It should be noted that only a small portion of each impacted $50 \mathrm{~m}$ cell is occupied by roads, skidtrails, landings, or large tree gaps; rather, the impacted $50 \mathrm{~m}$ cells provide a spatial estimate of areas where felling of trees and construction of logging access were likely to cause some associated canopy damage. The actual area of these logging features (computed from RDM 5 m cells) increased from $6.6 \%$ in 2010 to $23.7 \%$ in 2011 , an increase of $17.1 \%$. The proportion of the study area with canopy taller than $30 \mathrm{~m}$ dropped from $22.8 \%$ in 2010 to $18.7 \%$ in 2011 , a reduction of $4.1 \%$.

\subsection{Differences in lidar canopy metrics used for AGB estimation}

Paired t-tests of 2010 and 2011 P25 and VAR lidar metrics computed for the 50 ground plots and for those $50 \mathrm{~m}$ cells that were newly impacted between lidar acquisitions are given in Table 5. P25 decreased in 2011 and was significantly different $(P<0.01)$ between acquisitions; whereas, no significant difference was found for VAR $(P<0.59)$. For the newly impacted cells $(n=1691)$ which had a much higher amount of change due to selective logging P25 decreased and was significantly different $(P<0.0001)$; whereas, no significant difference was found for $\operatorname{VAR}(P<0.82)$.

\section{Discussion}

\subsection{Differences in lidar estimates of $A G B$ and lidar explanatory metrics}

In this study, we estimated AGB change to be $-9.1 \mathrm{Mg}^{-1}$ over the whole study area during the time between lidar acquisitions. In addition to a reduction in AGB associated with selective logging, one would expect an increase in AGB for residual trees due to growth during the 1.5 years between lidar acquisitions. AGB change due to logging alone is likely considerably more than lidar-predicted AGB change because lidar-based AGB change is the aggregate of all canopy change (growth, including regeneration in gaps, mortality, seasonal changes in leaf and flower mass, and reductions due to selective logging). Malhi et al. (2004) reported net stem wood productivity (growth, regeneration, and mortality) from 10 near-by natural forest sites in southern Peru to be approx. 3.5 $\mathrm{Mg} \mathrm{C} \mathrm{ha}^{-1} \mathrm{yr}^{-1}$ (approx. $7 \mathrm{Mg} \mathrm{ha}^{-1}$ AGB). Vieira et al. (2004) reported that a forest near Rio Branco, Brazil was accumulating $C$ in live AGB at rates of $1.0-1.5 \mathrm{Mg} \mathrm{Cha}^{-1} \mathrm{yr}^{-1}$ (approx. 2-3 $\mathrm{Mg} \mathrm{ha}^{-1} \mathrm{AGB}$ ). In a 12-year forest dynamics study in a bamboo dominated forest within FEA where similar selective logging had occurred, d'Oliveira, Guarino, Oliveira, Ribas, and Acuña (in press) estimated an annual AGB accumulation of approx. $7 \mathrm{Mg} \mathrm{ha}{ }^{-1} \mathrm{yr}^{-1}$ (standing trees and ingrowth). Similar growth $\left(7 \mathrm{Mg} \mathrm{ha}^{-1} \mathrm{yr}^{-1}\right.$ or $10 \mathrm{Mg} \mathrm{ha}{ }^{-1}$ AGB for the 1.5 years between lidar acquisitions, assuming a C:AGB conversion factor of 0.5 ) would be expected in our FEA study site. Aggregating this expected growth with AGB change, total reduction due to logging was likely at least $19 \mathrm{Mg} \mathrm{ha}^{-1}$ ( $8 \%$ of mean AGB) for the 


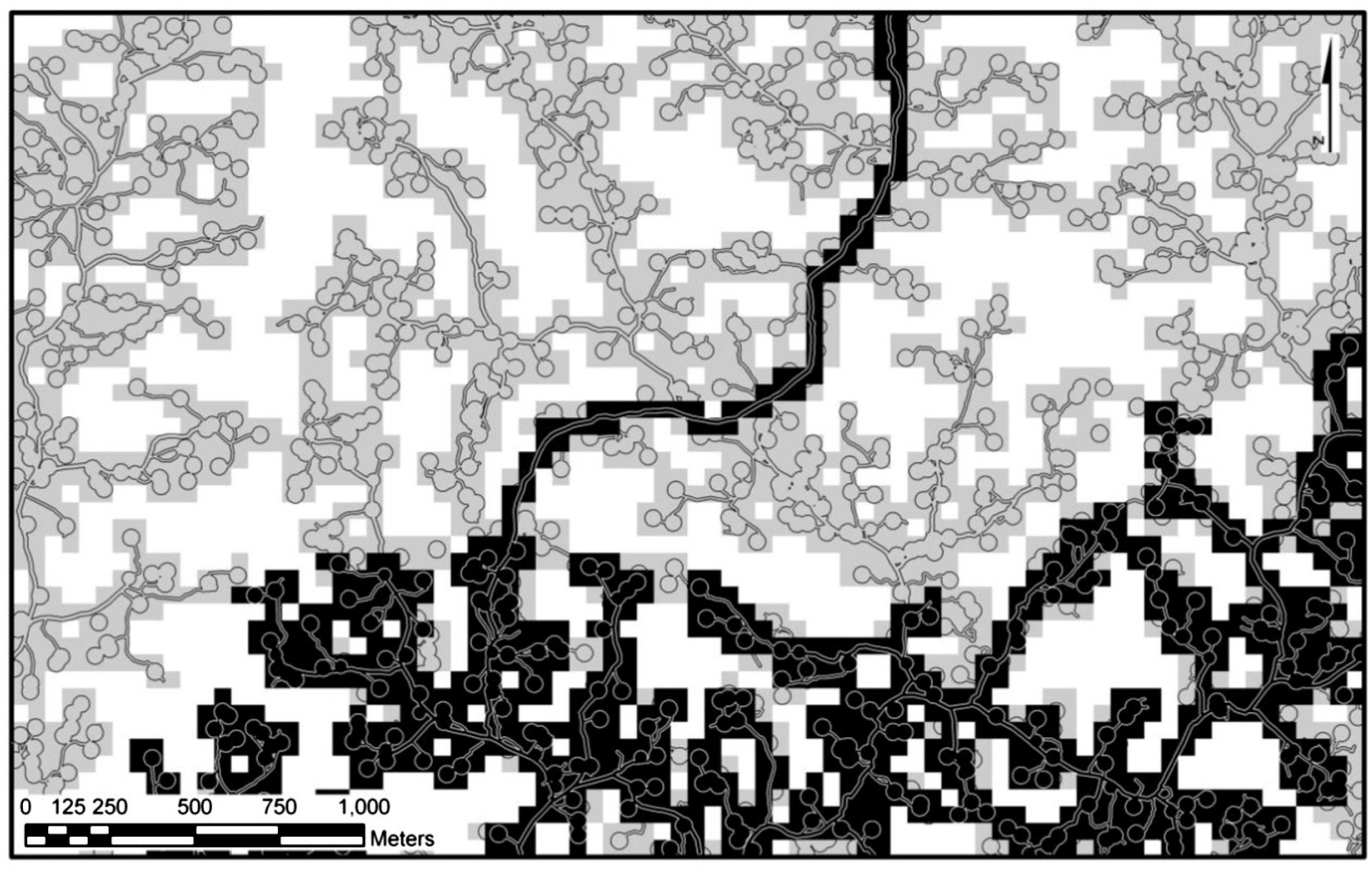

2010 Roads, Landings, Skidtrails

2011 Roads, Landings, Skidtrails

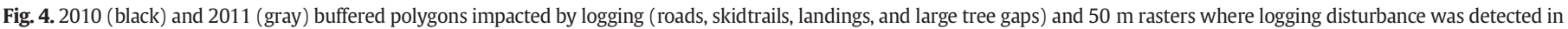
each lidar acquisition.

entire study area. These estimates are of the same magnitude as planned selectively logging removal rates $\left(10-15 \mathrm{~m}^{3} \mathrm{ha}^{-1} \approx 12-18 \mathrm{Mg} \mathrm{ha}^{-1}\right.$ AGB) for the entire site. It should be noted that to estimate periodic above ground carbon change, it is not necessary to estimate AGB change components (e.g., growth, logging removals, logging residuals, mortality), rather, only change in total AGB is needed.

In a prior study, d'Oliveira et al. (2012) used the 2010 lidar dataset in a model-assisted approach to estimate the mean AGB in several management units and for the entire area. A model-assisted approach could not be undertaken for 2011 AGB estimates (or for the change in AGB between 2010 and 2011) because a rigorous remeasurement of the ground plots that included diameter measurements of residual trees was not conducted at the time of the second lidar acquisition. Therefore, a model-based approach was used to obtain precision estimates for AGB change. Although this provides an indication of the precision of the AGB change, the assumptions underlying model-based and model-assisted approaches are different and the results are difficult to compare directly. However, given the high cost and logistical complexities associated with field work in remote areas, it is likely that this situation - where a remeasurement is acquired with lidar data but not field data - will be encountered quite commonly in the future. In these cases, the model-based approach presented here will provide a means to quantify the precision (and significance) of this estimated change, albeit under the assumptions of a model-based framework

In future studies, we recommend that a remeasurement of plots be conducted at the time of each lidar acquisition to allow model-assisted

Table 3

Lidar AGB $\left(\mathrm{Mg} \mathrm{ha}^{-1}\right)$ regression model.

\begin{tabular}{lrrrr}
\hline & Estimate & Std. error & t value & $P$-value \\
\hline Intercept & -132.67 & 38.93 & -3.41 & 0.001 \\
P25 & 16.18 & 2.84 & 5.69 & 0.000 \\
VAR & 2.08 & 0.26 & 7.99 & 0.000
\end{tabular}

estimates of AGB precision and eliminate any bias associated with using a regression developed from another time period or area.

Paired t-tests of the P25 lidar explanatory metric indicate that canopy structure had changed between acquisitions. d'Oliveira et al. (2012) note that P25 is likely well correlated with the center of mass (CM) of the AGB. Selective thinning removed predominately larger trees, resulting in a reduction in both the AGB and CM of the canopy. Selective logging did not appear to change VAR, likely because increases in VAR associated with new gaps in the canopy were likely offset by decreases in VAR caused by loss of larger, upper canopy trees. In future studies we recommend that, when possible, a control block (where logging is not planned) be flown in all acquisitions. This would provide more confidence in stability (and perceived changes) of lidar metrics between acquisitions. Additionally, such a control block would allow estimation of net change expected between acquisitions in the area not due to selective logging.

Table 4

Estimates of mean and change in AGB $\left(\mathrm{Mg} \mathrm{ha}^{-1}\right)$, the percent area of canopy that was greater than $30 \mathrm{~m}$ tall and change in tall canopy cover, the portion of study site identified as being roads, skidtrails, landings, or large tree gaps from the RDMs.

\begin{tabular}{|c|c|c|c|c|c|c|}
\hline & \multicolumn{2}{|l|}{2010} & \multicolumn{2}{|l|}{2011} & \multicolumn{2}{|l|}{ Change } \\
\hline & Area & AGB & Area & AGB & Area & AGB \\
\hline Total study site & $100.0 \%$ & 232.1 & $100.0 \%$ & 223.0 & $100.0 \%$ & -9.1 \\
\hline 50 m cells impacted by logging & $21.2 \%$ & 228.5 & $62.9 \%$ & 219.1 & $41.7 \%$ & - \\
\hline $\begin{array}{l}50 \text { m cells not impacted by } \\
\text { logging }\end{array}$ & $78.8 \%$ & 233.0 & $37.2 \%$ & 229.6 & $-\overline{41.7 \%}$ & - \\
\hline $\begin{array}{l}50 \text { m cells newly impacted in } \\
2011\end{array}$ & $42.3 \%$ & 236.4 & $42.3 \%$ & 218.4 & - & $\begin{array}{l}- \\
17.9\end{array}$ \\
\hline $\begin{array}{l}50 \text { m cells not newly impacted in } \\
2011\end{array}$ & $57.7 \%$ & 228.9 & $57.7 \%$ & 226.3 & - & -2.6 \\
\hline $1 \mathrm{~m}$ canopy cover $>30 \mathrm{~m}$ tall & $22.8 \%$ & - & $18.7 \%$ & - & $-4.1 \%$ & - \\
\hline 5 m cells RDM logging features & $6.6 \%$ & - & $23.7 \%$ & - & $17.1 \%$ & - \\
\hline
\end{tabular}


Table 5

Comparisons of lidar P25, and VAR explanatory variables between lidar acquisitions for the ground plots and the $50 \mathrm{~m}$ cells that were newly impacted in 2011 (two-tailed paired ttests).

\begin{tabular}{|c|c|c|c|c|c|}
\hline \multicolumn{4}{|c|}{ Paired t-test variables } & \multicolumn{2}{|c|}{ Paired t-test statistics } \\
\hline $\begin{array}{l}\text { Variable } \\
\text { name }\end{array}$ & $\begin{array}{l}\text { Variable } \\
\text { mean }\end{array}$ & $\begin{array}{l}\text { Variable } \\
\text { name }\end{array}$ & $\begin{array}{l}\text { Variable } \\
\text { mean }\end{array}$ & $\begin{array}{l}P \text { - } \\
\text { value }\end{array}$ & $\begin{array}{l}\text { Mean of } \\
\text { differences }\end{array}$ \\
\hline \multicolumn{6}{|c|}{ Total study area $(\mathrm{n}=50)$} \\
\hline 2010 P25 & 12.59 & 2011 P25 & 11.87 & 0.01 & -0.72 \\
\hline 2010 VAR & 77.04 & 2011 VAR & 77.68 & 0.59 & 0.64 \\
\hline \multicolumn{6}{|c|}{ Newly impacted cells $(\mathrm{n}=1691)$} \\
\hline 2010 P25 & 12.67 & 2011 P25 & 11.57 & 0.0001 & -1.10 \\
\hline 2010 VAR & 79.04 & 2011 VAR & 78.96 & 0.82 & -0.08 \\
\hline
\end{tabular}

\subsection{Changes in area impacted by selective logging and high canopy}

Examining Figs. 2(c) and 3(d), it is apparent that changes in tall overstory canopy $(30 \mathrm{~m}+)$ estimated directly from the CHMs, the expansion of roads, skidtrails, landings, and felled tree gaps detected in the 2011 RDM, and reductions in AGB are spatially correlated. The percentage of area in tall canopy was reduced considerably more in the northern two-thirds of the study area where most of the new selective logging occurred. Our reported portion of impacted area $(23.7 \%)$ is much higher than Pereira et al. (2002) reported for ground damaged by selective logging in the Eastern Amazon (approx. 5-10\%) despite the greater log volume extracted at those sites. This difference is likely attributed to different definitions and measurement methods. In our study we define impacted areas as those having low RDM values (i.e., areas where understory vegetation had likely been removed or crushed during logging activities). These impacted areas would include the actual road, skidtrail, and landing surfaces and adjacent areas where considerable understory damage had occurred as trees were felled, limbed, and skidded. We also included felled tree gaps. Pereira et al. (2002) restricted their definition to actual ground damage (road, skidtrail, and landing widths where soil damage or displacement occurred) and did not include felled tree gaps. Although these canopy and impact area changes are not useful in estimation of AGB change, they do provide corroborating evidence of the extent and spatial distribution of very low-intensity selective logging that is difficult to positively identify with the most remote sensing techniques.

\section{Conclusions}

This work demonstrates the potential of airborne lidar for quantification of structural changes (at both ground and canopy levels) in selectively logged tropical forests even at very low logging intensities. A modelbased approach was used to quantify the uncertainty of the change in AGB for the entire study area as well as impacted and non-impacted areas. These results indicate that lidar could be a valuable tool for REDD-related carbon monitoring systems, and may provide a means to quantify changes in aboveground carbon attributable to low-intensity selective logging activities that would be very difficult to detect using other forms of remote sensing (satellite imagery, etc.). In future studies, we recommend that lidar sensor and mission specifications remain similar. This will provide some level of confidence that AGB predictions (either generated using a regression model developed over similar forest sites, or from the same site, but applied with lidar data from a different acquisition as in the case of this study) are observations from the same "superpopulation" and therefore the assumptions behind model-based inference remain valid. Additionally, when possible, a control block where logging is not planned between lidar acquisitions should be flown to determine if there are any significant changes in lidar explanatory metrics. Further study is needed to determine if considerably lower lidar pulse densities $\left(1-4 \mathrm{~m}^{-2}\right)$ can provide similar results, while reducing acquisition costs.

\section{Acknowledgments}

Lidar data were acquired with support from the USDA Forest Service International Programs and USAID Sustainable Landscapes.

\section{Appendix A. Supplementary data}

Supplementary data associated with this article can be found in the online version, at http://dx.doi.org/10.1016/j.rse.2013.08.049. These data include Google maps of the most important areas described in this article.

\section{References}

Acre State (2010). Apresentação do sistema de incentivo a serviços ambientais. : Governo do Acre (30p. http://www.ac.gov.br Accessed 7 November 2012)

Acre e EMBRAPA/AC (2010). Inventario de Emissões Antrópicas e Sumidouros de Gases de Efeito Estufa do Estado do Acre: Ano - Base 2010. Rio Branco: Embrapa Acre (2012. 144p.).

Acre. Governo Do Estado Do Acre (2012). Relatório De Gestão 2011: Relatório Anual de Atividades do Instituto de Mudanças Climáticas e Regulação de Serviços Ambientais. Rio Branco: IMC

Andersen, H. E., Strunk, J., \& Temesgen, H. (2011). Using airborne lidar as a sampling tool for estimating forest biomass resources in the upper Tanana Valley of interior Alaska. Western Journal of Applied Forestry, 26, 57-164.

Angelsen, A. (Ed.). (2008). Moving Ahead with REDD: Issues, Options and Implications. Bogor, Indonesia: CIFOR.

Asner, G. P., Clark, J. K., Mascaro, J., Galindo García, G. A., Chadwick, K. D., Navarrete Encinales, D. A., et al. (2012). High-resolution mapping of forest carbon stocks in the Colombian Amazon. Biogeosciences Discussions, 9, 2445-2479. http://dx.doi.org/10.5194/bgd9-2445-2012 (2012).

Asner, G. P., Knapp, D. E., Broadbent, E. N., Oliveira, P. J. C., Keller, M., \& Silva, J. N. (2005). Selective logging in the Brazilian Amazon. Science, 310, 480-482. http://dx.doi.org/10. 1126/science.1118051 (2005).

Asner, G. P., Mascaro, J., Muller-Landau, H. C., Vieilledent, G., Vaudry, R., Rasamoelina, M., et al. (2011). A universal airborne LiDAR approach for tropical forest carbon mapping. Oecologia. http://dx.doi.org/10.1007/s00442-011-2165-z.

Asner, G. P., Powell, G. V. N., Mascaro, J., Knapp, D. E., Clark, J. K., Jacobson, J., et al. (2010) High-resolution forest carbon stocks and emissions in the Amazon. Proceedings of the National Academy of Sciences of the United States of America, 107, 16738-16742.

Baccini, A., Goetz, S. J., Walker, W. S., Laporte, N. T., Sun, M., Sulla-Menashe, D., et al (2012). Estimated carbon dioxide emissions from tropical deforestation improved by carbon-density maps. Nature Climate Change, 2, 182-185. http://dx.doi.org/10.1038/ nclimate1354.

Beets, P. N., Reutebuch, S., Kimberley, M., Oliver, G., Pearce, S., \& McGaughey, R. (2011). Leaf area index, biomass carbon and growth rate of radiata pine genetic types and relationships with LiDAR. Forests, 2(3), 637-659.

Bollandsås, O. M., Gregoire, T., Næsset, E., \& Øyen, B. -H. (2013). Detection of biomass change in Norwegian mountain forest using small footprint airborne laser scanner data. Statistical Methods E' Applications, 22(1), 113-129.

Chasmer, L., Hopkinson, C., Smith, B., \& Treitz, P. (2006). Examining the influence of changing laser pulse repetition frequencies on conifer forest canopy returns. Photogrammetric Engineering and Remote Sensing, 72, 1359-1367.

Curran, L. M., Trigg, S. N., McDonald, A. K., Astiani, D., Hardiono, Y. M., Siregar, P., et al. (2004). Lowland forest loss in protected areas of Indonesian Borneo. Science, 303 1000-1003.

Dubayah, R. O., Sheldon, S. L., Clark, D. B., Hofton, M. A., Blair, J. B., Hurtt, G. C., et al. (2010) Estimation of tropical forest height and biomass dynamics using lidar remote sensing at La Selva, Costa Rica. Journal of Geophysical Research, 115, 1-17 G00E09. http://dx. doi.org/10.1029/2009JG000933

d'Oliveira, M. V. N., Reutebuch, S. E., McGaughey, R. J., \& Andersen, H. -E. (2012). Estimating forest biomass and identifying low-intensity logging areas using airborne scanning lidar in Antimary State Forest, Acre State, Western Brazilian Amazon. Remote Sensing of Environment, 124, 479-491.

d'Oliveira, M. V. N., Guarino, E. S., Oliveira, L. C., Ribas, L. A., \& Acuña, M. H. A. (2013). Can forest management be sustainable in a bamboo forest? A 12-year case study of forest dynamics in western Amazon. : Forest Ecology and Management (in press).

ESRI (2011). ArcGIS Desktop: Release 9.3. Redlands, CA: Environmental Systems Research Institute.

Gobakken, T., Næsset, E., Nelson, R., Bollandsås, O. M., Gregoire, T. G., Ståhl, G., et al. (2012). Estimating biomass in Hedmark County, Norway using national forest inventory field plots and airborne laser scanning. Remote Sensing of Environment, 123, 443-456.

Gonzalez, P., Asner, G. P., Battles, J. J., Lefsky, M.A., Waring, K. M., \& Palace, M. (2010). Forest carbon densities and uncertainties from lidar, QuickBird, and field measurements in California. Remote Sensing of Environment, 114, 1561-1575.

Goodwin, N. R., Coops, N. C., \& Culvenor, D. S. (2006). Assessment of forest structure with airborne LiDAR and the effects of platform altitude. Remote Sensing of Environment, 103, 140-152.

Harris, N. L., Brown, S., Hagen, S.C., Baccini, A., \& Houghton, R. (2012). Progress toward a consensus on carbon emissions from tropical deforestation. Winrock International 
and Woods Hole Research Center (Washington, D.C. and Woods Hole, MA.) ISBN 978-0-615-72677-9. Research, 42, 605-613. http://dx.doi.org/10.1139/X2012-018.

Harris, N. L., Brown, S., Hagen, S.C., Saatchi, S. S., Petrova, S., Salas, W., et al. (2012a). Baseline map of carbon emissions from deforestation in tropical regions. Science, 336, 1573-1575. http://dx.doi.org/10.1126/science.1217962.

Hopkinson, C. (2007). The influence of flying altitude, beam divergence, and pulse repetition frequency on laser pulse return intensity and canopy frequency distribution. Canadian Journal of Remote Sensing, 33, 312-324.

Hudak, A. T., Strand, E. K., Vierling, L. A., Byrne, J. C., Eitel, J. U. H., Martinuzzi, S., et al. (2012). Quantifying aboveground forest carbon pools and fluxes from repeat LiDAR surveys. Remote Sensing of Environment, 123, 25-40.

Instituto Nacional de Pesquisas Espaciais (INPE) (2013). Projeto PRODES: Monitoramento Da Floresta Amazônica Brasileira Por Satélite. http://www.obt.inpe.br/prodes/index. php (n.d., Accessed April 16, 2013)

Keller, M., Asner, G. P., Silva, J. M. N., \& Palace, M. (2004b). Sustainability of selective logging of upland forests in the Brazilian Amazon: Carbon budgets and remote sensing as tools for evaluation of logging effects. In D. J. Zarin, J. Alavalapati, F. E. Putz, \& M. Schmink (Eds.), Working Forests in the American Tropics: Conservation Through Sustainable Management? (pp. 41-63). New York: Colombia University Press0-231-12907-6.

Keller, M., Palace, M., Asner, G. P., Pereira, R., Jr., \& da Silva, J. N. M. (2004a). Coarse woody debris in undisturbed and logged forests in the eastern Brazilian Amazon. Global Change Biology, 10, 784-795. http://dx.doi.org/10.1111/j.1529-8817.2003.00770.x.

Kellner, J. R., Clark, D. B., \& Hubbell, S. P. (2009). Pervasive canopy dynamics produce short-term stability in a tropical rain forest landscape. Ecology Letters, 12, 155-164. http://dx.doi.org/10.1111/j.1461-0248.2008.01274.x.

Koch, B. (2010). Status and future of laser scanning, synthetic aperture radar and hyperspectral remote sensing data for forest biomass assessment. ISPRS Journal of Photogrammetry and Remote Sensing, 65(6), 581-590.

Li, Y., Andersen, H. -E., \& McGaughey, R. (2008). A comparison of statistical methods for estimating forest biomass from light detection and ranging. Western Journal of Applied Forestry, 23(4), 223-231.

Lumley, T. (2009). Leaps: Regression Subset Selection (Using Fortran Code by Alan Miller). http://CRAN.R-project.org/package=leaps (Accessed 20 October 2012)

Magnussen, S., Næsset, E., \& Gobakken, T. (2010). Reliability of LiDAR derived predictors of forest inventory attributes: A case study with Norway spruce. Remote Sensing of Environment, 114, 700-712.

Magnusson, M., Fransson, J. E. S., \& Holmgren, J. (2007). Effects on estimation accuracy of forest variables using different pulse density of laser data. Forest Science, 53, 619-626.

Malhi, Y., Baker, T. R., Phillips, O. L., Almeida, S., Alvarez, E., Arroyo, L., et al. (2004). The above-ground coarse wood productivity of 104 Neotropical forest plots. Global Change Biology, 10(5), 563-591. http://dx.doi.org/10.1111/j.1529-8817.2003.00778.x.

McGaughey, R. J. (2010). FUSION/LDV: Software for LIDAR Data Analysis and Visualization. : United States Department of Agriculture, Forest Service, Pacific Northwest Research Station (154 pp., http://forsys.cfr.washington.edu/fusionlatest.html, accessed November 2012)

McRoberts, R. E., Næsset, E., \& Gobakken, T. (2013). Inference for lidar-assisted estimation of forest growing stock volume. Remote Sensing of Environment, 128, 268-275.

Meyer, V., Saatchi, S. S., Chave, J., Dalling, J., Bohlman, S., Fricker, G. A., et al. (2013). Detecting tropical forest biomass dynamics from repeated airborne Lidar measurements. Biogeosciences Discussions, 10, 1957-1992.

Morsdorf, F., Frey, O., Meier, E., Itten, K. I., \& Allgöwer, B. (2008). Assessment of the influence of flying altitude and scan angle on biophysical vegetation products derived from airborne laser scanning. International Journal of Remote Sensing, 29, 1387-1406.
Næsset, E. (2009). Effects of different sensors, flying altitudes, and pulse repetition frequencies on forest canopy metrics and biophysical stand properties derived from small-footprint airborne laser data. Remote Sensing of Environment, 113, 148-159.

Næsset, E. (2011). Estimating above-ground biomass in young forests with airborne laser scanning. International Journal of Remote Sensing, 32(2), 473-501.

Næsset, E., \& Gobakken, T. (2008). Estimation of above- and below-ground biomass across regions of the boreal forest zone using airborne laser. Remote Sensing of Environment, 112, 3079-3090.

Nogueira, E. M., Fearnside, P.M., Nelson, B. W., Barbosa, R. I., \& Keizer, E. W. H. (2008). Estimates of forest biomass in the Brazilian Amazon: New allometric equations and adjustments to biomass from wood-volume inventories. Forest Ecology and Management, 256(11), 1853-1867.

Nyström, M., Holmgren, J., \& Olsson, H. (2012). Prediction of tree biomass in the foresttundra ecotone using airborne laser scanning. Remote Sensing of Environment, 123, 271-279.

Optech Inc. (2008). http://www.optech.ca/pdf/Brochures/ALTM3100EAwspecsfnl.pdf (last accessed on 21 October 2013)

Pereira, D., Santos, D., Vedoveto, M., Guimarães, J., \& Veríssimo, A. (2010). Fatos Florestais da Amazônia. Belém, Pará: Imazon (124pp.).

Pereira, R., Jr., Zweede, J. C., Asner, G. P., \& Keller, M. (2001). Forest canopy damage and recovery in reduced impact and conventional selective logging Eastern Para, Brazil. Forest Ecology and Management, 168, 77-89.

Pereira, R., Zweede, J. C., Asner, G. P., \& Keller, M. (2002). Forest canopy damage and recovery in reduced impact and conventional selective logging in eastern Para, Brazil. Forest Ecology and Management, 168, 77-89. http://dx.doi.org/10.1016/S0378-1127(01) 00732-0.

Picard, N., Gourlet-Fleury, S., \& Forni, E. (2012). Estimating damage from selective logging and implications for tropical forest management. Canadian Journal of Forest, 28(3), 278-295.

Pinard, M.A., \& Putz, F. E. (1996). Retaining forest biomass by reducing logging damage. Biotropica, 28, 278-295.

R Development Core Team (2012). R: A Language and Environment for Statistical Computing. Vienna, Austria: R Foundation for Statistical Computing.

St-Onge, B., \& Vepakomma, U. (2004). Assessing forest gap dynamics and growth using multi-temporal laser-scanner data. In M. Thies, B. Koch, H. Spiecker, \& H. Weinacker (Eds.), Laser-scanners for forest and landscape assessment. Proceedings of the ISPRS working group VIII/2. International Archives of Photogrammetry. : Remote Sensing and Spatial Information Sciences Vol. XXXVI, Part 8/W2. (pp. 173-178)

Vieira, S., Camargo, P. B., Selhorst, D., Silva, R., Hutyra, L., Chambers, J. Q., et al. (2004). Forest structure and carbon dynamics in Amazonian tropical rain forest. Oecologia, 140, 468-479.

Weishampel, J. F. Hightower, J. N. Chase, A. F. \& Chase, D. Z (2012). Use of airborne LiDAR to delineate canopy degradation and encroachment along the GuatemalaBelize border. Tropical Conservation Science, 5(1), 12-24.

Wright, S. J. (2010). The future of tropical forests. Annals of the New York Academy of Sciences, 1195, 1-27.

Yu, X., Hyyppa, J., Hyyppa, H., \& Maltamo, M. (2004). Effects of flying altitude on tree height estimation using airborne laser scanning. In M. Thies, B. Koch, H. Spiecker, \& H. Weinacker (Eds.), Proceedings of the ISPRS working group VIII/2: Laser - scanners for forest and landscape assessment, XXXVI Part 8/W2, : Institute for Forest Growth; Institute for Remote Sensing and Landscape Information Systems. 